\section{Araştırma Makalesi / Research Article}

Fizik / Physics
Iğdır Üniversitesi Fen Bilimleri Enstitüsü Dergisi, 9(4): 2097-2104, 2019

Journal of the Institute of Science and Technology, 9(4): 2097-2104, 2019

\title{
Electrochemical Capacitance of Annealed High-Carbon Steel in Aqueous and Non-aqueous Electrolytes
}

\author{
Abdulcabbar YAVUZ ${ }^{*}$, Kaan KAPLAN ${ }^{2}$
}

ABSTRACT: High-carbon steel was heat treated in a furnace at $400{ }^{\circ} \mathrm{C}, 600{ }^{\circ} \mathrm{C}$ and $800{ }^{\circ} \mathrm{C}$ for 30 minutes. Annealed and non-annealed high carbon steels were immersed in aqueous ( $\mathrm{KOH}$ and $\left.\mathrm{Na}_{2} \mathrm{SO}_{4}\right)$ and non-aqueous (choline chloride and urea based ionic liquid called Reline) electrolyte in order to understand their electrochemical behavior depending on different annealing temperatures. The aim of this research is to understand the heat treatment effect on capacitance performance of high-carbon steel. The areal capacitance of heat treated and nonheat treated high carbon steel was calculated based on applied elevated temperatures. The roughness of highcarbon steel increased after thermal oxidation. The current density and specific capacitance increased upon increasing annealing temperature of high carbon steel charged/discharged in $\mathrm{KOH}$ electrolyte. The capacitance of steel heat-treated at $800{ }^{\circ} \mathrm{C}$ was 50 times greater than that of non-annealed steel in $\mathrm{KOH}$. The areal capacitance of high-carbon steel scanned in $\mathrm{Na}_{2} \mathrm{SO}_{4}$ increased as annealing temperature increased. The specific capacitance of steel annealed at high temperature in $\mathrm{Na}_{2} \mathrm{SO}_{4}$ was greater than that in $\mathrm{KOH}$ and in Reline electrolyte. Although non-annealed and $400{ }^{\circ} \mathrm{C}$ annealed high carbon steel was electrochemically inactive in Reline ionic liquid, the specific capacitance of steel treated at $600{ }^{\circ} \mathrm{C}$ and $800{ }^{\circ} \mathrm{C}$ increased significantly in Reline. Reline, $\mathrm{Na}_{2} \mathrm{SO}_{4}$ and $\mathrm{KOH}$ could be used conveniently as supercapacitor electrolyte with annealed high-carbon steels.

Keywords: Heat treatment, high-carbon steel, cyclic voltammetry, capacitance

\section{Sulu ve Sulu Olmayan Elektrolitlerde Tavlanmış Yüksek Karbonlu Çeliğin Elektrokimyasal Kapasitansı}

ÖZET: Yüksek karbonlu çelik $400{ }^{\circ} \mathrm{C}, 600{ }^{\circ} \mathrm{C}$ ve $800{ }^{\circ} \mathrm{C}$ sıcaklıktaki firında 30 dakika süreyle 1sıl işleme tabi tutuldu. Tavlanmış ve tavlanmamış yüksek karbonlu çeliklerin, farklı tavlama sıcaklıklarına bağlı olarak elektrokimyasal davranışlarını anlamak için sulu ( $\mathrm{KOH}$ ve $\left.\mathrm{Na}_{2} \mathrm{SO}_{4}\right)$ ve susuz (Reline adı verilen kolin klorür ve üre bazlı iyonik sıvı) elektrolitler içerisine daldırıldı. Isıl işlem görmüş ve görmemiş yüksek karbonlu çeliklerin alan kapasitansı uygulanan yüksek sıcaklıklara göre hesaplanmıştır. Termal oksidasyondan sonra yüksek karbonlu çeliğin pürüzlülüğü artmıştır. Mevcut yoğunluk ve spesifik kapasitans, $\mathrm{KOH}$ elektrolitinde şarj/deşarj edilen yüksek karbon çeliğinin tavlama sıcaklığının artması üzerine artmıştır. $800{ }^{\circ} \mathrm{C}$ 'de 1 sıl işlem görmüş çeliğin kapasitansı KOH'daki tavlanmamış çelikten 50 kat daha büyüktü. $\mathrm{Na}_{2} \mathrm{SO}_{4}$ 'te taranan yüksek karbonlu çeliğin alan kapasitansı tavlama sıcaklığı yükseldikçe artmıştır. Yüksek sıcaklıkta tavlanan çeliğin $\mathrm{Na}_{2} \mathrm{SO}_{4}$ 'taki spesifik kapasitans1, KOH ve Reline elektrolitinde olduğundan daha büyüktü. Tavlanmamış ve $400{ }^{\circ} \mathrm{C}$ 'de tavlanmış yüksek karbonlu çeliklerin Reline iyonik sıvısında elektrokimyasal olarak etkin olmamasına rağmen, $600{ }^{\circ} \mathrm{C}$ 'de ve $800{ }^{\circ} \mathrm{C}$ 'de işlenen çeliğin Reline'daki spesifik kapasitansı önemli ölçüde artmıştır. Reline, $\mathrm{Na}_{2} \mathrm{SO}_{4}$ ve $\mathrm{KOH}$ süper kapasitör elektroliti olarak tavlanmış yüksek karbonlu çeliklerle rahatlıkla kullanılabilir.

Anahtar Kelimeler: Isıl işlem, yüksek karbonlu çelik, döngüsel voltmetre, kapasitans

\footnotetext{
1 Abdulcabbar YAVUZ (Orcid ID: 0000-0002-7216-0586), Department of Metallurgical and Materials Engineering, Faculty of Engineering, Gaziantep University, Sehitkamil, Gaziantep, Turkey

2 Kaan KAPLAN (Orcid ID: 0000-0003-0631-1961), Department of Engineering Physics, Faculty of Engineering, Gaziantep University, Sehitkamil, Gaziantep, Turkey

*Sorumlu Yazar / Corresponding Author: Abdulcabbar YAVUZ, e-mail: ayavuz@gantep.edu.tr

Geliş tarihi / Received: 26.07.2019

Kabul tarihi / Accepted: 09.09.2019
} 


\section{INTRODUCTION}

Steel is prepared from the mixture of some elements with iron and carbon because their physical properties could be significantly tailored by changing the ratio of alloying elements and heat treatment process. Steel can be divided into three subgroups depending on the ratio of carbon as low-carbon steel, medium-carbon steel and high-carbon steel (Krauss 2015). There are some requirements for a material to be considered as low-carbon steel. Carbon content has to be maximum of $0.3 \%$, manganese cannot be more than $1.65 \%$ and silicon has to be maximum 0.6 $\%$ (Oberg et al. 2008). Low-carbon steel is mostly used in automotive industry and bridge construction. However, it must meet with some certain conditions such as formability, weldability and durable to fracture (Kao et al. 1990). Formability of steel differs according to its carbon amount inside the composition that small amount of it makes a material highly formable. With this property low carbon steels become indispensable materials for automotive industry (Chen and Yeun 2003). Medium-carbon steels have different material ratio composition. The amount of other elements in the composition of low carbon steel does not generally affect its property (Daramola, Adewuyi, and Oladele 2015). Carbon ratio of medium carbon steel is more than that of low-carbon type which is between 0.3 and 0.6 (\% by weight) and manganese should be between 0.6 and 1.65 ( $\%$ by weight). This type of steel is requested material in order to make shaft, axles, and railway wheels (Singh 2015). High-carbon steel (used in this study) has carbon ration between 0.6 and 1.0 (\% by weight) with 0.3 and 0.9 (\% by weight) manganese (Lesuer et al. 1993). With highcarbon amount, material becomes more durable and gains more strength that these properties can be increased with higher carbon amount in the composition.

Heat treatment or annealing of a substance is a usual process that occasionally can be essential for materials to gain specific properties (Isfahany, Saghafian, and Borhani 2011; Kosturek et al. 2018; Movahed et al. 2009). In terms of steels particularly ferrous types, heat treatment effects structure and specification significantly (Totten 2006). The main reason of annealing is to change the structural properties of steel such as ductility, strength and impact durability (Hsu and Xu 2007). Annealing could change surface properties such as corrosion resistivity (Fang et al., 2015), wear behavior and electroactivity of material. Researches were conducted to understand the electrochemical behavior of non-annealed and annealed highcarbon steel (Osório et al. 2009). In this study high carbon steel is oxidized at high temperature and electrochemical behavior of annealed steel is compared with non-annealed steel in different electrolyte for supercapacitor applications. The main aim of this research is to understand the heat treatment effect on electrochemical properties of high-carbon steel obtained at $400{ }^{\circ} \mathrm{C}, 600{ }^{\circ} \mathrm{C}$ and $800{ }^{\circ} \mathrm{C}$.

\section{MATERIAL AND METHODS}

High-carbon steel (CK75) was used as a working electrode in this study. Components of the steel are shown in Table 1.. Steel which had the size of $3 \mathrm{~cm} \times 4 \mathrm{~cm}$ and $0.2 \mathrm{~mm}$ thick was divided into 3 equal pieces to be examined at different temperatures. Three sample pieces (each $4 \mathrm{~cm}^{2}$ ) were left in the furnace at $400{ }^{\circ} \mathrm{C}$, $600{ }^{\circ} \mathrm{C}$ and $800{ }^{\circ} \mathrm{C}$ respectively and each of them held for 30 minutes. Before annealing, the surfaces of high carbon steel were ground using 600, 1000 and 2000 mesh sandpaper. 
Table 1: Chemical composition of high-carbon steel used in this work.

\begin{tabular}{cccccccc}
\hline Element & $\mathrm{C}$ & $\mathrm{Mn}$ & $\mathrm{Si}$ & $\mathrm{P}$ & $\mathrm{S}$ & $\mathrm{Cr}$ & Others \\
\hline Content (\% wt.) & 0.75 & 0.70 & 0.25 & $<0.025$ & $<0.025$ & - & - \\
\hline
\end{tabular}

When the annealing process was finished, the first annealed steel sample at $400{ }^{\circ} \mathrm{C}$ was split into 3 equal pieces to be analyzed in different electrolytes. The first electrolyte was $\mathrm{KOH}$ (potassium hydroxide) and $1.3 \mathrm{~cm}^{2}$ annealed steel at $400{ }^{\circ} \mathrm{C}$ was prepared to immerse in the $1 \mathrm{M}$ $\mathrm{KOH}$. However, to be able to understand which voltage range was going to be suitable for steel in $\mathrm{KOH}$, firstly non-annealed steel was immersed in the alkaline media and wide voltage range was scanned by using three electrode cells with the help of the VersaSTAT 3 potentiosat device (AMETEK, the USA). Titanium coated platinum (99.9\% purity) was used as a counter electrode. $\mathrm{Ag}$ wire or $\mathrm{Ag} / \mathrm{AgCl}$ containing $3.5 \mathrm{M} \mathrm{KCl}$ solution was used as reference electrode in nonaqueous and aqueous electrolyte. The working electrode was annealed or non-annealed highcarbon steel. After non-annealed steel was polarized, it has been seen that high-carbon steel was not active as its current density was very low (typically around $100 \mu \mathrm{A} \mathrm{cm} \mathrm{cm}^{-2}$ ) between $-0.4 \mathrm{~V}$ and $0.5 \mathrm{~V}$. Steels that were annealed at $400{ }^{\circ} \mathrm{C}$, $600{ }^{\circ} \mathrm{C}$ and $800{ }^{\circ} \mathrm{C}$ were immersed in the $1 \mathrm{M}$ $\mathrm{KOH}$ electrolyte respectively at this voltage range.

Other three high-carbon steels (annealed at $400{ }^{\circ} \mathrm{C}, 600{ }^{\circ} \mathrm{C}$ and $800{ }^{\circ} \mathrm{C}$ ) were ready to put in the $\mathrm{Na}_{2} \mathrm{SO}_{4}$ media respectively. Non-annealed steel was again put in the $0.5 \mathrm{M} \mathrm{Na} \mathrm{NO}_{4}$ electrolyte in order to understand the non-active voltage range of the steel. It was observed that high-carbon steel was not active from $-0.45 \mathrm{~V}$ to $-1 \mathrm{~V}$. Thereafter steel specimens annealed at different temperatures were put in the $\mathrm{Na}_{2} \mathrm{SO}_{4}$ at this voltage range. The remaining three steel pieces (annealed at $400{ }^{\circ} \mathrm{C}, 600{ }^{\circ} \mathrm{C}$ and $800{ }^{\circ} \mathrm{C}$ ) were prepared to cycle in Reline. Reline is an ionic liquid prepared by the mixture of 2 moles of choline chloride with 1 mole of urea (Smith, Abbott, and Ryder 2014). Non-annealed steel was scanned in Reline. It was understood that high-carbon steel was not active between $-0.6 \mathrm{~V}$ and $0.6 \mathrm{~V}$ in Reline and therefore this range was used while scanning annealed low carbon steel in Reline. After all these processes, characteristics and electrochemical behavior of high-carbon steel were observed using the cyclic voltammograms. As a last step their specific capacitance dependence was calculated in every media.

\section{RESULTS AND DISCUSSION}

Cyclic polarization of heated (at $400{ }^{\circ} \mathrm{C}$, $600{ }^{\circ} \mathrm{C}$ and $800{ }^{\circ} \mathrm{C}$ ) and without heated highcarbon steels in $1 \mathrm{M} \mathrm{KOH}$ were performed and their cyclic polarization responses are displayed in Figure 1. All experiments were conducted at a temperature of $23 \pm 2{ }^{\circ} \mathrm{C}$. In this figure potential window was chosen between $-0.4 \mathrm{~V}$ and $0.5 \mathrm{~V}$ according to the non-active region that nonannealed high-carbon steel was around 0 ampere. It was observed that current densities of the samples rose with increased temperature. There was a significant increase in terms of current density when high carbon steel annealed at 800 ${ }^{\circ} \mathrm{C}$ was cycled in alkaline electrolyte. The cyclic voltammogram shape of high carbon steel annealed at $800{ }^{\circ} \mathrm{C}$ in $\mathrm{KOH}$ is the characteristic of supercapacitor behavior. The current densities of all annealed specimens have a great tendency to increase and decrease after $0.5 \mathrm{~V}$ and $-0.4 \mathrm{~V}$, respectively as shown in Figure 1. It was concluded that this potential range for high- 
carbon steel in $1 \mathrm{M} \mathrm{KOH}$ was an appropriate potential window.

The specific capacitance of non-annealed and annealed high-carbon steel in $\mathrm{KOH}$ electrolyte was calculated and presented in Table 2. Areal capacitance was changing with increasing temperature that there was a proportional increase but not linear. The areal capacitance of non-annealed and $600{ }^{\circ} \mathrm{C}$ annealed high carbon steel is close to each other. However, areal capacitance of at $800{ }^{\circ} \mathrm{C}$ heat treated steel increased significantly and capacitance of $800{ }^{\circ} \mathrm{C}$ heat treated steel was almost 5 times higher than that of non-heat treated steel. Areal capacitance graph of heat treated and non-heat treated high carbon steel is given in Figure 2. The areal capacitance of annealed steel was calculated using Equation 1.

$$
C_{A}=\int \frac{i \cdot d V}{v \cdot A} \quad \text { Equation } 1
$$

where $C_{A}$ is the areal capacitance in $\mathrm{F} \mathrm{g}^{-1}$ of annealed high carbon steel, $i$ is the area of the cyclic voltammetric curve for oxidation in Coulombs, $v$ is the scan rate in $\mathrm{V} \mathrm{s}^{-1}$ and ' $A$ ' is the area of the heated carbon steel.

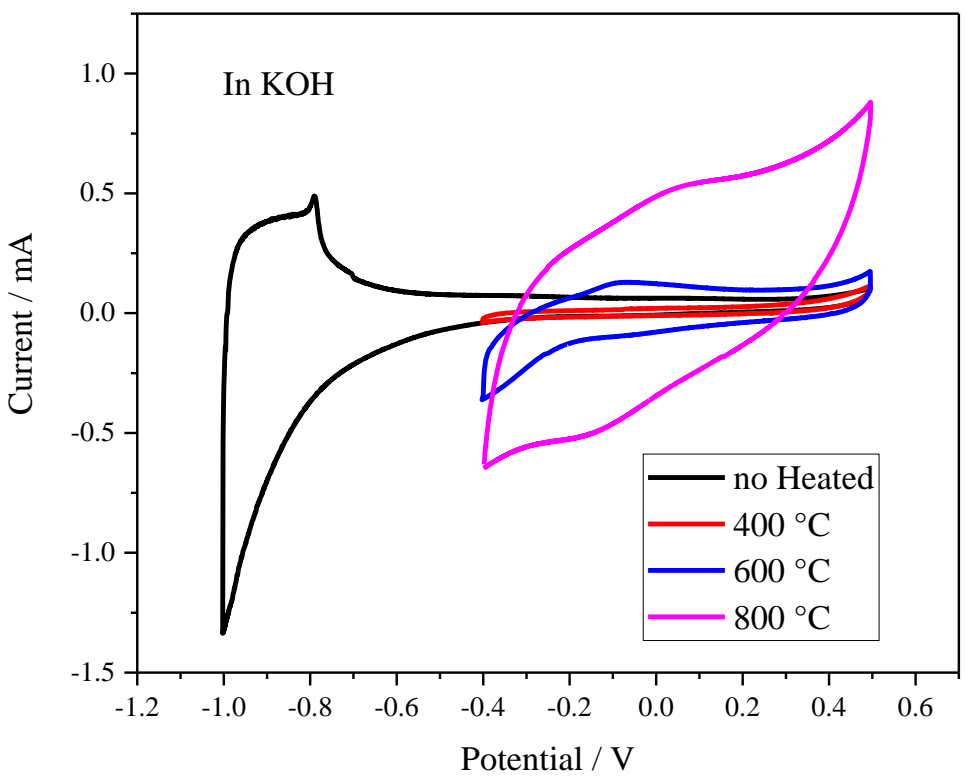

Figure 1. Cyclic voltammograms of non-annealed and annealed high-carbon steel in $1 \mathrm{M}$ potassium hydroxide. Titanium coated platinum was performed as a counter electrode, $\mathrm{Ag}-\mathrm{AgCl}$ was performed as reference electrode and high-carbon steel was working electrode. The scan rate was $20 \mathrm{mV} \mathrm{s}^{-1}$

Table 2: specific capacitance values of non-annealed and annealed (at $400{ }^{\circ} \mathrm{C}, 600{ }^{\circ} \mathrm{C}$ and $800{ }^{\circ} \mathrm{C}$ ) high- carbon steel scanned in $\mathrm{KOH}, \mathrm{Na}_{2} \mathrm{SO}_{4}$ and Reline media

\begin{tabular}{|c|c|c|c|}
\hline & In KOH media $\left(\mathrm{mF} \mathrm{cm}^{-2}\right)$ & In $\mathrm{Na}_{2} \mathrm{SO}_{4}$ media $\left(\mathrm{mF} \mathrm{cm}^{-2}\right)$ & In ionic liquid Reline $\left(\mathrm{mF} \mathrm{cm}^{-2}\right)$ \\
\hline Non-annealed & 0.13 & 3.4 & 0.09 \\
\hline $400^{\circ} \mathrm{C}$ annealed & 0.38 & 5.4 & 0.08 \\
\hline $600^{\circ} \mathrm{C}$ annealed & 1.3 & 11.4 & 1.2 \\
\hline $800{ }^{\circ} \mathrm{C}$ annealed & 6.3 & 12.4 & 1.2 \\
\hline
\end{tabular}




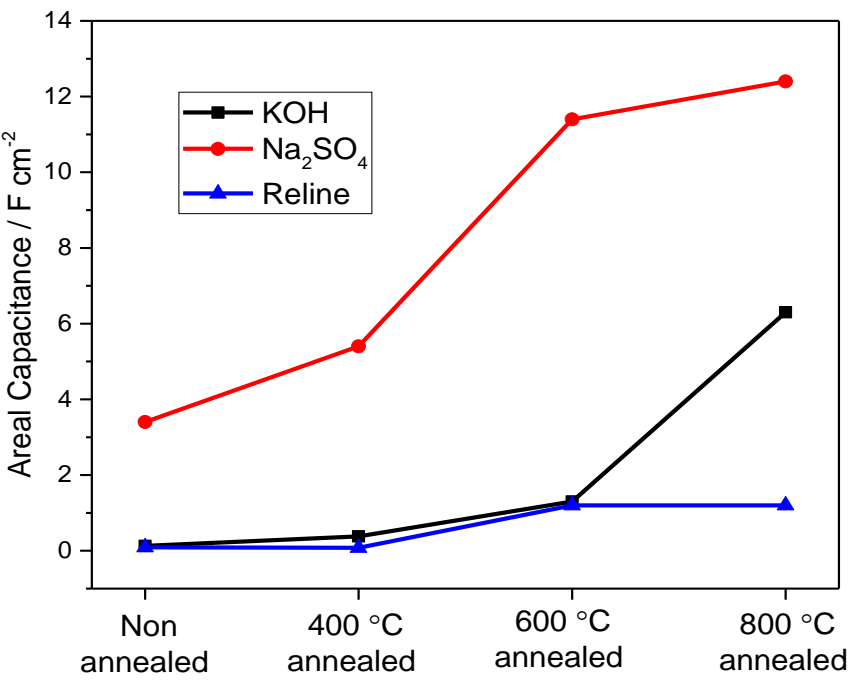

Figure 2: Areal capacitance of annealed and non-annealed high carbon steel in different electrolytes. Data were retrieved from Figure 1, Figure 4 and Figure 5

Photograph of high carbon steels depending on heat treatment is given in Figure 3. $20 \mathrm{~mm}$ of each steel strip was cycled in $\mathrm{KOH}$. Non-annealed high carbon steel was shiny and its color was metallic grey (see the top side of Figure 3a). After $\mathrm{KOH}$ polarization, its color was changed to lighter metallic grey (see bottom side of Figure 3a). High carbon steel annealed at 400 ${ }^{\circ} \mathrm{C}$ became bluish grey as it was oxidized as presented in Figure 3b. Alkaline polarization did not significantly change the color of $400{ }^{\circ} \mathrm{C}$ annealed high carbon steel. When $600{ }^{\circ} \mathrm{C}$ and 800 ${ }^{\circ} \mathrm{C}$ annealing temperature were applied to highcarbon steel, its color was dark grey and brown, (see Figure 3c and Figure 3d, respectively). The color of these two metal strips was not changed after they were cycled in $\mathrm{KOH}$ electrolyte. The brown color of high carbon steel annealed at 800 ${ }^{\circ} \mathrm{C}$ refers to iron oxide that can be formed at high temperatures, particularly after around $700{ }^{\circ} \mathrm{C}$ (Chen and Yeun 2003).

Figure 4 represents the cyclic polarization of non-annealed and annealed high-carbon steel samples in sodium sulfate media. The effect of surface morphology on electrochemical properties of $\mathrm{FeCo}_{2} \mathrm{O}_{4}$ electrodes in $\mathrm{Na}_{2} \mathrm{SO}_{4}$ electrolyte was studied elsewhere (Chodankar et al. 2017). The current density of the non-annealed steel proved that the potential window could be chosen between $-0.45 \mathrm{~V}$ and $-1.0 \mathrm{~V}$ because steel was electrochemically inactive in this potential range. While the potential was scanned from $0.45 \mathrm{~V}$ to a positive voltage, there was gaseous output both on working electrode and counter electrode that current density increased quickly to $250 \mathrm{~mA}$ from 0 ampere level. Besides, as can be seen in Figure 4, the current densities of annealed steels increased upon increasing annealing temperature in this media. Beyond $-1.0 \mathrm{~V}$, the current activity of high-carbon steel had a great tendency to decrease. Therefore, this potential range was suitable window to be able to observe the electrochemical behavior of steel in $0.5 \mathrm{M}$ $\mathrm{Na}_{2} \mathrm{SO}_{4}$. The specific capacitance of nonannealed and annealed high-carbon steel in this media was calculated and it became clear that capacitance increased with temperature. The specific capacitance of annealed steel in $\mathrm{Na}_{2} \mathrm{SO}_{4}$ media was greater than that in $\mathrm{KOH}$ as shown in Figure 2. 


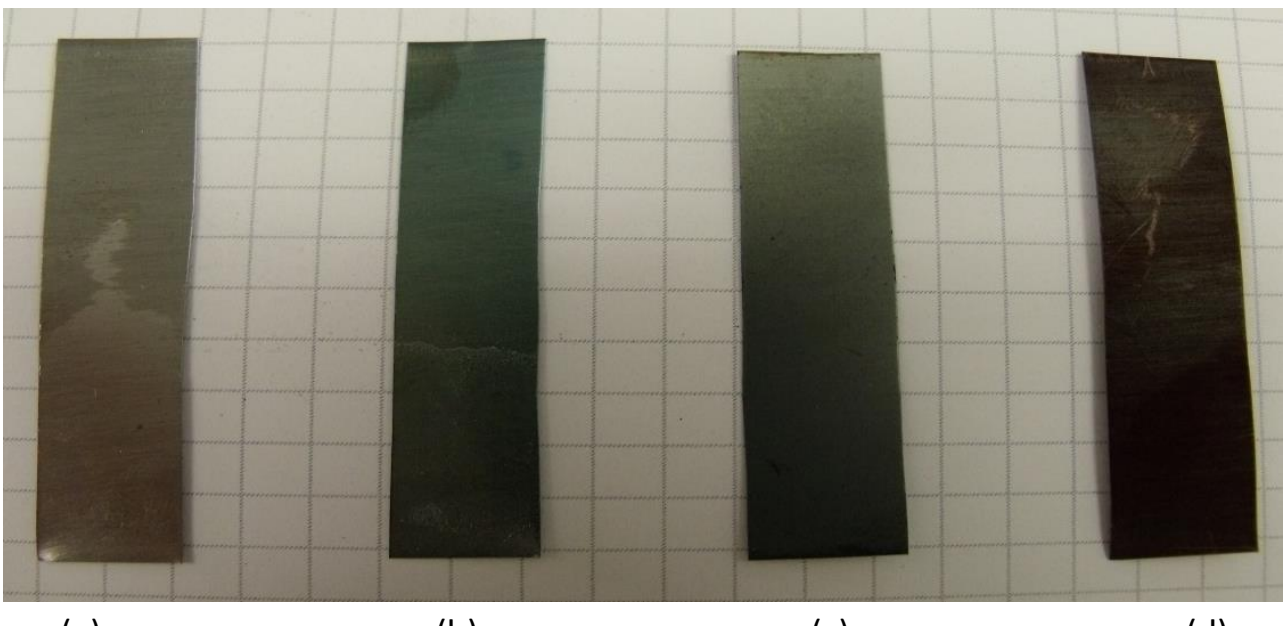

(a)

(b)

(c)

(d)

Figure 3. Photos of steel specimens after cyclic polarization process in $1 \mathrm{M} \mathrm{KOH}$. The bottom side of the specimens was immersed in the alkaline media. Photos of a) $5 \mathrm{~cm}^{2}(5 \mathrm{~cm} \times 1 \mathrm{~cm})$ non-annealed high-carbon steel, b) $5 \mathrm{~cm}^{2}$ high-carbon steel annealed at $400{ }^{\circ} \mathrm{C}$, c) $5 \mathrm{~cm}^{2}$ high-carbon steel annealed at $600{ }^{\circ} \mathrm{C}$, d) $1.3 \mathrm{~cm}^{2}$ high-carbon steel annealed at $800{ }^{\circ} \mathrm{C}$
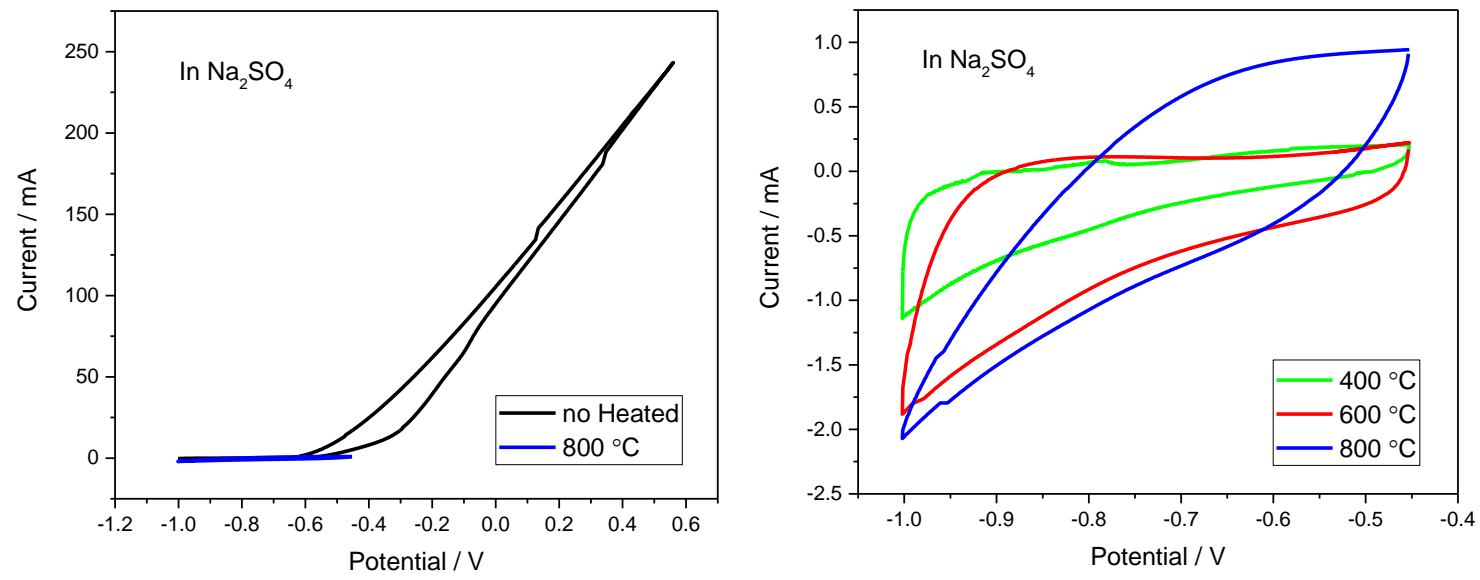

Figure 4. Cyclic voltammogram responses of high-carbon steel in $0.5 \mathrm{M} \mathrm{Na}_{2} \mathrm{SO}_{4}$. While green, red and blue lines represent annealed steels at $400{ }^{\circ} \mathrm{C}, 600{ }^{\circ} \mathrm{C}$ and $800{ }^{\circ} \mathrm{C}$ respectively, black line is the non-annealed steel at the scan rate of $20 \mathrm{mV} \mathrm{s}^{-1}$. All experiments were performed at room temperature $\left(20 \pm 2{ }^{\circ} \mathrm{C}\right)$

High-carbon steel was transferred to one of the ionic liquid: Reline. The potential window was chosen based on cyclic polarization of nonannealed steel in Reline electrolyte. First a wide voltage range from $-1.0 \mathrm{~V}$ to $0.6 \mathrm{~V}$ was chosen in order to monitor the inactive potential window. The potential window between $-0.6 \mathrm{~V}$ and $0.6 \mathrm{~V}$ was selected to cycle annealed high carbon steel in Reline because the cyclic voltammetric curves of steel in Figure 5 has the current density of steel around 0 ampere meaning that steel is electrochemically inactive in this range and suitable for polarization study of heat-treated high carbon steel sheet. Electrochemical behavior of annealed steels responded differently at this potential window. The amount of current density increased with elevated temperatures, particularly after $400{ }^{\circ} \mathrm{C}$. Reline could be a convenient electrolyte to observe electrochemical behavior of high-carbon steel annealed at high temperatures. The specific capacitance of nonannealed and annealed high carbon steel cycled 
in Reline was tabulated in Table 2 and shown in Figure 2. It was realized that specific capacitance of non-annealed and annealed steel at $400{ }^{\circ} \mathrm{C}$ was similar. Although the specific capacitance of high carbon steel cycled in Reline was increased significantly after annealing at $600{ }^{\circ} \mathrm{C}$ and 800 ${ }^{\circ} \mathrm{C}$, the capacitance value obtained in Reline was less than that in the other electrolytes.

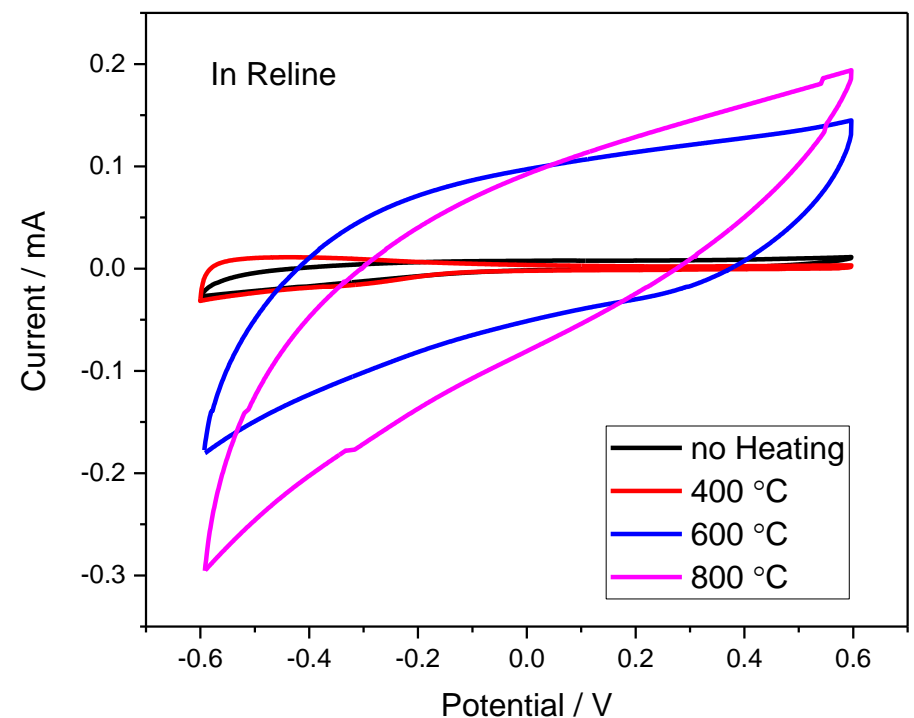

Figure 5. Cyclic voltammogram of non-annealed and annealed steel in Reline ionic liquid. Reline was prepared from 2 moles of choline chloride with 1 mole of urea (Smith, Abbott, and Ryder 2014). High-carbon steel was working electrode, titanium coated platinum was a counter electrode and $\mathrm{Ag}$ wire was performed as reference electrode at $20 \mathrm{mV} \mathrm{s}^{-1}$ scan rate

\section{CONCLUSION}

High-carbon steel composed of $0.3 \%$ of carbon and $0.4 \%$ of manganese was annealed at $400{ }^{\circ} \mathrm{C}$, $600{ }^{\circ} \mathrm{C}$ and $800{ }^{\circ} \mathrm{C}$. Annealed high carbon steels were then immersed in different electrolytes $\mathrm{KOH}$ (potassium hydroxide), $\mathrm{Na}_{2} \mathrm{SO}_{4}$ (Sodium sulfate) and Reline in order to understand their electrochemical behavior depending on different annealing temperatures. The areal capacitance of heat treated and nonheat treated high carbon steel was calculated based on elevated temperatures. Surface morphology of non-annealed and annealed high carbon steel depending on oxidation temperature was analyzed.

High-carbon steel had a shiny surface before annealing. With the annealing process shiny surface was disappeared and oxidized layer occurred on the surface. Increasing annealing temperature caused to turn the color of high carbon steel to darker. The oxidation layer was very obvious that turned into a brownish color after annealed at $800{ }^{\circ} \mathrm{C}$. In $\mathrm{KOH}$ electrolyte the current density increased with increased temperatures that reached its maximum value at $800{ }^{\circ} \mathrm{C}$. The capacitance of high-carbon steel annealed at $800{ }^{\circ} \mathrm{C}$ was $6.3 \mathrm{mF} \mathrm{cm}^{-2}$ in $\mathrm{KOH}$ electrolyte and it was 50 times greater than the capacitance of the non-annealed high-carbon steel in $\mathrm{KOH}$.

Electrochemical behavior of high-carbon steel in $\mathrm{Na}_{2} \mathrm{SO}_{4}$ for non-annealed steel was around 0 ampere and it was electrochemically inactive. The current density of the samples prepared at high temperature increased and reached its maximum value when high carbon steel obtained at $800{ }^{\circ} \mathrm{C}$ was cycled in $\mathrm{Na}_{2} \mathrm{SO}_{4}$. The specific capacitance of high-carbon steel in $\mathrm{Na}_{2} \mathrm{SO}_{4}$ was greater than that in $\mathrm{KOH}$ electrolyte. The electrochemical responses of carbon steel 
annealed at $400{ }^{\circ} \mathrm{C}$ was nearly inactive the same as non-annealed steel in Reline ionic liquid. However, the current density of high carbon steel treated at $600{ }^{\circ} \mathrm{C}$ and $800{ }^{\circ} \mathrm{C}$ increased significantly in Reline. The specific capacitance values of non-annealed and annealed high carbon steel in Reline were not high compared to that in the other electrolytes. High areal capacitance and the usability of annealed high carbon steel at room temperature make these electrodes a suitable candidate for supercapacitor applications.

\section{ACKNOWLEDGMENT}

Kaan Kaplan would like to thank the Council of Higher Education for 100/2000 YOK Doctoral Scholarship program. This work was supported by Gaziantep University (project number MF.YLT.17.03).

\section{REFERENCES}

Chen RY, Yeun WYD, 2003. Review of the HighTemperature Oxidation of Iron and Carbon Steels in Air or Oxygen. Oxidation of metals, 59(5-6): 433-68.

Chodankar NR, Dubal DP, Kwon Y, Kim DH, 2017. Direct growth of FeCo $2 \mathrm{O} 4$ nanowire arrays on flexible stainless steel mesh for high-performance asymmetric supercapacitor. NPG Asia Materials, 9(8): e419.

Daramola OO, Adewuyi BO, Oladele IO, 2015. Effects of Heat Treatment on the Mechanical Properties of Rolled Medium Carbon Steel. Journal of Minerals and Materials Characterization and Engineering, 09(08): 693-708.

Fang XX, Zhou HZ, Xue YJ, 2015. Corrosion properties of stainless steel $316 \mathrm{~L} / \mathrm{Ni}-\mathrm{Cu}-\mathrm{P}$ coatings in warm acidic solution. Transactions of Nonferrous Metals Society of China, 25(8): 2594-2600.

Hsu TY, Xu ZY, 2007. Design of Structure, Composition and Heat Treatment Process for High Strength Steel. In Materials Science Forum, Trans Tech Publ, 2283-86.
Isfahany AN, Saghafian H, Borhani G, 2011. The Effect of Heat Treatment on Mechanical Properties and Corrosion Behavior of AISI420 Martensitic Stainless Steel. Journal of Alloys and Compounds, 509(9): 3931-36.

Kao AS, Kuhn HA, Spitzig WA, Richmond O, 1990. Influence of superimposed hydrostatic pressure on bending fracture and formability of a low carbon steel containing globular sulfides. Journal of Engineering Materials and Technology, 112(1), 26-30.

Kosturek R, Najwer M, Nieslony P, Wachowski M, 2018. Effect of Heat Treatment on Mechanical Properties of Inconel 625/Steel P355NH Bimetal Clad Plate Manufactured by Explosive Welding. In Advances in Manufacturing, Springer, 681-86.

Krauss G, 2015. Steels: Processing, Structure, and Performance. Asm International. Ohio, the USA

Lesuer DR, Syn CK, Goldberg A, Wadsworth J, Sherby OD, 1993. The case for ultrahigh-carbon steels as structural materials. JOM, 45(8), 40-46.

Movahed P, Kolahgar S, Marashi SPH, Pouranvari M, Parvin N, 2009. The effect of intercritical heat treatment temperature on the tensile properties and work hardening behavior of ferritemartensite dual phase steel sheets. Materials Science and Engineering: A, 518(1-2), pp.1-6.

Oberg E, Jones FD, Horton HL, Ruffle HH, 2008. Machinery's Handbook 28th Edition. Industrial Press Inc. New York

Osório WR, Peixoto LC, Garcia LR, Garcia A, 2009. Electrochemical Corrosion Response of a Low Carbon Heat Treated Steel in a $\mathrm{NaCl}$ Solution."Materials and Corrosion, 60(10): 80412.

Singh R, 2015. Applied Welding Engineering: Processes, Codes, and Standards. 2nd Edition, Butterworth-Heinemann. Oxford, UK

Smith EL, Abbott AP, Ryder KS, 2014. Deep Eutectic Solvents (DESs) and Their Applications. Chemical Reviews, 114(21): 11060-82.

Totten GE, 2006. Steel Heat Treatment: Metallurgy and Technologies. 2nd Edition, CRC press. Oregon, the USA 